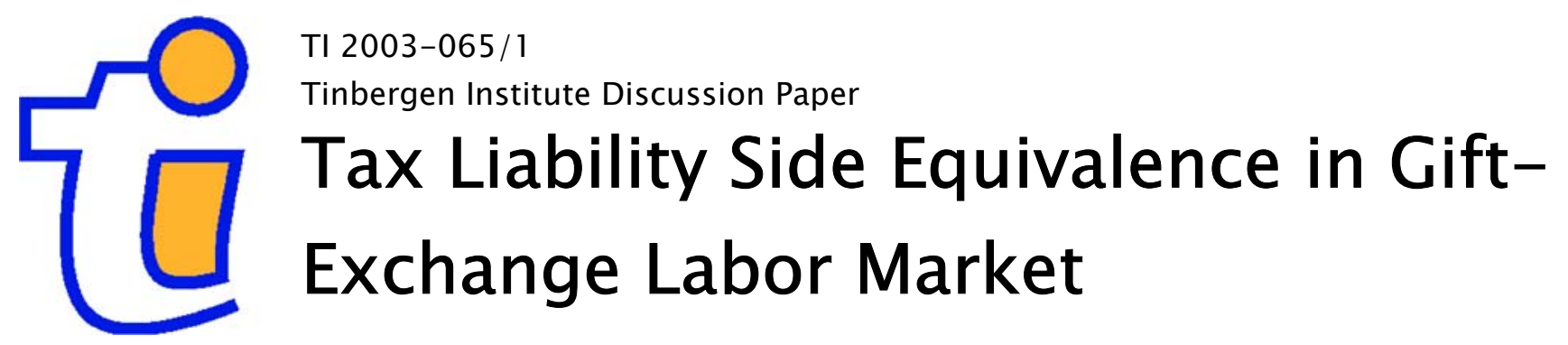

\author{
Arno Ried/I \\ Jean-Robert Tyran²
}

${ }^{\prime}$ Department of Economics (CREED), Faculty of Economics and Econometrics, University of Amsterdam, and Tinbergen Institute,

2 Department of Economics, University of St. Gallen, Switzerland. 


\section{Tinbergen Institute}

The Tinbergen Institute is the institute for economic research of the Erasmus Universiteit Rotterdam, Universiteit van Amsterdam, and Vrije Universiteit Amsterdam.

Tinbergen Institute Amsterdam

Roetersstraat 31

1018 WB Amsterdam

The Netherlands

Tel.: $\quad+31(0) 205513500$

Fax: $\quad+31(0) 205513555$

Tinbergen Institute Rotterdam

Burg. Oudlaan 50

3062 PA Rotterdam

The Netherlands

Tel.: $\quad+31(0) 104088900$

Fax: $\quad+31(0) 104089031$

Please send questions and/or remarks of nonscientific nature to driessen@tinbergen.nl.

Most TI discussion papers can be downloaded at http://www.tinbergen.nl. 


\title{
Tax Liability Side Equivalence in Gift-Exchange Labor Markets
}

\author{
Arno Riedl $^{*}$ and Jean-Robert Tyran ${ }^{* *}$
}

\begin{abstract}
August 2003
Tax Liability Side Equivalence (tax LSE) claims that the statutory incidence of a tax is irrelevant for its economic incidence. In gift-exchange labor markets, firms provide a gift to workers by paying high wages, and workers reciprocate by providing high efforts. Tax LSE is theoretically predicted to hold in gift-exchange markets if workers' effort choices exclusively depend on the net wage, but breaks down if they partially depend on the gross wage paid to workers. We experimentally test tax LSE in a gift-exchange market and find that it holds surprisingly well.
\end{abstract}

Keywords: Tax incidence, Efficiency wages, Gift exchange, Experiments.

JEL-codes: C92, H22, J41.

Tinbergen Institute and University of Amsterdam. Department of Economics (CREED), Roetersstraat 11, NL1018 WB Amsterdam.

a.m.riedl@uva.nl

** University of St. Gallen. Department of Economics, Bodanstr. 1, CH-9000 St. Gallen.

Jean-Robert.Tyran@unisg.ch

We thank Jan-Willem Burgers, Simon Gächter, Rupert Sausgruber and participants at seminars in Amsterdam for helpful comments, and Jos Theelen for programming the experiment. We are grateful for financial support by the Oesterreichische Nationalbank under project no. 6933. 


\section{Introduction}

This paper experimentally investigates Tax Liability Side Equivalence (tax LSE) ${ }^{1}$ in gift-exchange labor markets. Tax LSE is a basic tenet of public economics. It claims that the statutory incidence (i.e., who legally pays a tax) is irrelevant for economic incidence (i.e., who bears the tax burden). In the words of Musgrave (1959: 351), "it is a matter of indifference whether a general tax on transactions is assessed on the seller's or on the buyer's side of the market" (see Stiglitz 1988: Ch. 17 or Fullerton and Metcalf 2003 for detailed accounts). However, public debate in the media and the political arena is often much concerned with statutory incidence (see Borck et al. 2002 or Ruffle 2001 for examples of such public concern). This is particularly true for debates about who should pay social security contributions in labor markets. Blinder (1988: 12) pointed to this discrepancy between economic theory and public concern by stating:

“... consider what may be the most basic theorem of public finance: the irrelevance of the side of the market on which a tax is levied. We all had fun explaining to our beginning students why it doesn't matter whether the payroll tax is levied on employers or employees. Then why, perhaps we should wonder, do Congress, labor and management all think the decision so momentous? Sheer lack of understanding? Maybe. But maybe not."

One plausible reason for this discrepancy is that the assumptions on which the theoretical prediction of tax LSE hinges are not met in reality. In particular, tax LSE is predicted to hold in labor markets only if gross wages adjust to the changes in taxation and if market participants are exclusively concerned with net (i.e., after-tax) profits and wages. Accordingly, tax LSE does not hold, for example, if wages cannot freely adjust due to exogenous reasons (e.g., when minimum wages are binding), if income taxation is nonproportional (e.g., is progressive, see Lockwood and Manning 1993), or if unemployment benefits are related to workers' gross wages (Picard and Toulemonde 2001).

Besides these exogenous ("institutional") reasons for this discrepancy, endogenous wage rigidity provides another potential explanation for public concern with statutory

\footnotetext{
1 Tax liability side equivalence is sometimes also called "Dalton's Law" (after Hugh Dalton 1922) or
} "Invariance of Incidence Proposition". 
incidence. If wages are endogenously rigid, adjustment to the new equilibrium levels after a change in statutory incidence is sluggish. In this case, tax LSE does not hold in the short run, but may hold in the long run. This is also the explanation Blinder (1988: 12) provides for the apparent discrepancy:

"I submit that part of the answer is ... that we economists insist on thinking longrun equilibrium while everyone else lives in short-run disequilibrium. The truth of the matter is that the incidence of the payroll tax may differ dramatically in the short and long runs."

Efficiency wages have been suggested as a prime explanation for endogenous real wage rigidity (e.g., Bewley 1999). Yet, tax LSE is predicted to nevertheless hold in efficiency wage labor markets, as long as all market participants base their decisions on net wages and profits (see, e.g., Pisauro 1991). In principle, this is also true for gift-exchange labor markets, in which firms provide a gift to workers by paying high wages while hoping to elicit high efforts in exchange from reciprocally motivated workers (Akerlof 1982). This paper focuses on tax LSE in gift exchange markets for two reasons. First, gift exchange has been identified as a particularly relevant reason for why efficiency wages are paid (e.g., Campbell and Kamlani 1997). Second, social norms play an important role in gift-exchange markets, and these social norms may cause tax LSE to break down if they induce market participants to take gross wages into account. This will be the case if workers perceive the tax to be external to the giftexchange relation between the firm and the worker.

To illustrate that tax LSE fails to hold in this case, consider the two polar cases where the tax is either fully assessed on firms or fully assessed on workers (these polar cases also serve as the basis of our experiment). A tax on labor drives a wedge between the firm's cost of employing workers and the net wage a worker obtains. As a consequence, the wage paid by firms is a net wage if the tax is assessed on firms, while it is a gross wage if the tax is assessed on workers. Suppose that, for some reason, workers evaluate the generosity of a gift according to the wage paid by the firm, not according to how much this wage is worth after tax. In other words, suppose that workers evaluate the generosity of the gift according to the net wage in case the tax is assessed on firms, but according to the gross wage in case the tax is assessed on workers. Given this evaluation by workers, firms are willing to pay higher net wages when the tax is assessed on firms if this induces profit-maximizing amounts of effort from reciprocal workers. A change of statutory incidence may, therefore, lead to a change in 
net wages. In particular, net wages will increase when statutory incidence is changed from workers to firms, but will fall if statutory incidence is changed from firms to workers. Hence, tax LSE fails to hold.

There are two possible explanations for why workers might evaluate the generosity of the gift according to the wage paid by the firm. The first is a kind of tax illusion, i.e., a "sheer lack of understanding" (see first quote above) that taxes are at least partially shifted to the other side of a market. Alternatively, workers may deem it fair that the market side who is legally liable to pay the tax also ought to bear the tax. This explanation has been suggested by Kerschbamer and Kirchsteiger (2000) who provide a model in which such a norm leads to the breakdown of tax LSE. These explanations may, however, also interact. Workers may, for example, believe that the tax will not be shifted because they deem changing the terms of the firm-worker relation unfair. Whatever the exact reason for why workers evaluate the generosity of the gift according to the wage paid, the effect in any case is a tendency for taxes to "stick where they hit".

In this study, we experimentally investigate whether tax LSE holds in efficiency wage labor markets of the gift exchange type. We use an experimental approach because it has important advantages over field studies. In particular, changes in tax regimes can be implemented in a controlled manner in the laboratory and relevant market outcomes can be observed over time under otherwise constant market conditions. This enables us to investigate whether tax incidence does indeed "differ dramatically in the short and the long runs" (see second quote above). The experimental gift-exchange markets we investigate are institutions combining competitive markets with bilateral bargaining. In such institutions, fairness concerns are important because market outcomes depend on the perceived fairness of the rent distribution (Fehr, Kirchsteiger and Riedl [henceforth FKR] 1993, 1998).

Investigating an institution that combines aspects of competitive markets and bargaining is particularly relevant because the empirical literature provides no answer to the question whether tax LSE holds in these markets. On the one hand, studies that have experimentally tested tax LSE in competitive experimental goods markets (Kachelmeier, Limberg and Schadewald 1994, Borck et al. 2002 and Ruffle 2001), tend to find that LSE holds. On the other hand, Kerschbamer and Kirchsteiger (2000) provide evidence that tax LSE does not hold in a bilateral bargaining experiment. 
Our study, to the best of our knowledge, is the first to investigate how wages, efforts and rents are affected by statutory incidence in efficiency-wage labor markets. Our experimental design allows us to test tax LSE in gift-exchange markets along three dimensions. We find that tax LSE holds surprisingly well along all three dimensions. In particular, we find that a change in tax regimes does not significantly affect relevant market outcomes, like the distribution of incomes between workers and firms, even in the short run.

We proceed as follows. Section 2 discusses the advantages of an experimental economics approach to tax LSE, and relates our study to the literature. Section 3 explains the experimental design, section 4 presents the experimental results, and section 5 concludes.

\section{An experimental approach to tax liability side equivalence}

Public debate is often much concerned with who should pay social security contributions, as noted in the introduction. A casual look at how social security contributions are statutorily split between employers and employees in different countries reveals no clear pattern. In some countries, contributions are equally split (e.g., in Germany, Japan, and the United States), in many countries the employers' share exceeds the employees' share (e.g., in France, Italy and Sweden), while it is the other way around in a few countries (e.g., Australia, Denmark, and The Netherlands, see OECD 2000: 167).

These casual observations provide no clear indication whether statutory tax incidence actually affects economic incidence. Should an equal split be taken as an indication that fairness concerns are particularly important in these countries? Does the fact that the employers' share exceeds the employees' share reflect that employers actually bear a larger burden in these countries? Or are these differences just random and economically irrelevant policy outcomes? We believe that these casual observations warrant none of these speculations.

An ideal test for tax LSE involves a comparison of market outcomes in two theoretically equivalent tax regimes under otherwise unchanged economic conditions. Such a test is unlikely to occur in the field. Consider the most clear-cut case in which exclusively statutory taxation of social security is changed. Yet, judging whether the two tax regimes in fact are equivalent is fraught with difficulties even in this case. The reason is that the rate of ad valorem taxes must be adjusted for the regimes to be equivalent. A correct adjustment 
necessitates knowledge of supply and demand elasticities which is usually not available in the field. Furthermore, the identification of potential impact effects of a change in taxation is beset by anticipatory effects. In practice, tax reforms are publicly debated and therefore announced. Hence, behavioral changes may occur before the new tax regime is in place. The problems of identifying whether two tax regimes are theoretically equivalent are even exacerbated when the type of taxation is changed (see Ruffle 2001 for a discussion of switching from sales taxes to value added or broad consumption taxes). While these problems pertain to testing tax LSE in general, obtaining field data to test whether tax LSE fails because of endogenous wage rigidity is even more difficult. To do so, one would have to investigate an environment in which wages are completely free to adjust. However, labor markets are often regulated to the effect that wages cannot be changed at discretion (e.g., because of minimum wage laws or long-term wage contracts).

We argue that our experimental approach creates an ideal environment to test whether tax LSE fails for endogenous reasons, and whether it holds in the long run. In the laboratory, a change in the tax regime can be implemented while holding all other market parameters constant, and control of information conditions allows for unanticipated changes in tax regimes. Since we observe the distribution of rents in a market in which exogenous frictions are absent, we can test whether tax LSE fails to hold because of endogenous wage rigidity. Finally, by running the market for several periods under constant conditions (a technique called stationary replication), we can investigate whether tax LSE holds on impact, only in the long run, or not at all.

Considering these important advantages of an experimental approach, and given that tax LSE is the "most basic theorem of public finance" (see first quote above), surprisingly few experimental studies on tax LSE are available to date. And none of the previous studies analyzes efficiency-wage labor markets. Kachelmeier et al. (1994) study consumption taxes in a relatively complex double auction involving consumers, retailers and producers. The authors compare the effects of ad valorem taxes on consumers and retailers and of valueadded taxes on producers and retailers. Surprisingly, they observe that those who legally pay the tax tend to bear the least burden. However, their overall conclusion is that tax LSE cannot be rejected by the data. Borck et al. (2002) investigate tax LSE of specific taxes in a postedoffer market. They examine two treatments in which some periods of trading without tax are followed by some periods in which a tax is either assessed on the sellers or the buyers. Their between-subject comparison of the two tax regimes provides clear support for tax LSE. Ruffle 
(2001) examines tax and subsidy LSE in so-called pit markets. After a few rounds without tax or subsidy, a specific tax or a specific subsidy is imposed on either buyers or sellers. The results provide strong support for tax and subsidy LSE. Taken together, these three studies clearly indicate that tax LSE holds in competitive goods markets. This seems to be true independent of the precise price formation mechanism or differences in framing.

In stark contrast to the studies cited above, Kerschbamer and Kirchsteiger (2000) find that tax LSE does not hold in a simple bargaining experiment. The authors use the wellknown ultimatum game (Güth, Schmittberger and Schwarze 1982) in which a proposer makes a take-or-leave offer to a responder. To test tax LSE, the authors run experimental treatments where either the proposer or the responder has to pay a specific tax upon acceptance of the offer. Their main finding is that the side that legally pays the tax also bears a higher economic burden. The authors suggest that tax LSE holds in competitive goods markets but was found not to hold in their experiment because fairness norms play a much more important role in bargaining than in competitive markets. Since fairness norms have been shown to be particularly important in competitive gift-exchange labor markets, it is an open question whether tax LSE holds in such markets.

Our experimental study builds on FKR (1993). These authors investigate the giftexchange hypothesis experimentally and find strong support for it. The authors study competitive posted-bid markets in which firms offer wages and workers - who are in excess supply - compete for jobs. Upon acceptance of a wage offer, the worker chooses an effort level. By design, efforts are positively related to firm profits but negatively related to worker income. Importantly, the firm cannot force the worker to provide more than minimal effort, and reputation building is excluded by design because firms and workers are anonymous. The main finding is that firms persistently pay wages above the reservation wage and that there is a strong positive correlation between wages paid and efforts provided. While a number of follow-up studies has shown that this gift-exchange relationship is a robust phenomenon (e.g., Hannan, Kagel and Moser 2002; for overviews see Fehr and Gächter 2000 or Camerer 2003), we do not know of any study analyzing the endogenous rigidity of wages after a change in taxation. 


\section{Experimental Design and Procedures}

\subsection{General description}

The basic idea of this study is to implement a gift-exchange market with pronounced efficiency-wage characteristics, and to assess a tax either on the supply side (i.e., on workers) or on the demand side (i.e., on firms). Our design has two treatments with two tax regimes each. The treatments exclusively differ with respect to the sequencing of tax regimes. In the tax regime called ToF (Tax on Firms), the tax is levied on firms, while in the regime called ToW (Tax on Workers) it is levied on workers. Each tax regime constitutes a phase, consisting of 16 trading periods each. The sequence of tax regimes is either ToF in phase 1 and ToW in phase 2 [treatment ToF/ToW], or vice versa [treatment ToW/ToF], see table 1.

Table 1: Experimental treatments

\begin{tabular}{|l|c|c|}
\cline { 2 - 3 } \multicolumn{1}{c|}{} & $\begin{array}{c}\text { Phase 1 } \\
\text { (periods 1-16) }\end{array}$ & $\begin{array}{c}\text { Phase 2 } \\
\text { (periods 17-32) }\end{array}$ \\
\hline Treatment ToF/ToW & Tax on Firms & Tax on Workers \\
& ToF(1) & ToW(2) \\
\hline Treatment ToW/ToF & Tax on Workers & Tax on Firms \\
& ToW(1) & ToF(2) \\
\hline
\end{tabular}

This design allows us to test tax LSE along three dimensions. First, we can compare the two tax regimes across treatments in a given period. By comparing tax regimes $\mathrm{ToF}(1)$ with ToW(1), and $\operatorname{ToF}(2)$ with ToW(2), we test for tax LSE while holding the experience of subjects with the market institution constant. Because each subject participates in one treatment only, the comparison across treatments is also a comparison across subjects. Such an across-subjects test is statistically particularly powerful because market prices are strictly independent observations. Second, we are able to compare the two tax regimes within a given treatment. By comparing tax regimes in a given row of table 1, i.e., by comparing $\operatorname{ToF}(1)$ with ToW(2) and ToW(1) with ToF(2), we analyze the effect of a change of taxation while holding 
everything else (e.g., the identity of market participants) constant. This within-subjects comparison provides a demanding test for tax LSE. This test is demanding because tax LSE may not hold in the short run but may well hold in the long run. Hence, the test involves observing whether tax shifting is instantaneous or takes some time. Third, we can compare the same tax regime across treatments and phases. By comparing diagonal cells in table 1, i.e., by comparing $\operatorname{ToF}(1)$ with $\operatorname{ToF}(2)$ and $\operatorname{ToW}(1)$ with $\operatorname{ToW}(2)$, we test for sequencing and experience effects. For example, it may be the case that workers feel entitled to the wage previously paid, and that, as a consequence, the equilibrium wage in a particular tax regime depends on the market wages in the previous tax regime.

\subsection{Procedures and Parameters}

Each period of the experiment has the following two-stage structure. In the first stage, each firm simultaneously chooses one integer wage offer $W=\{1, \ldots, 100\}$. These wage offers are posted on participants' computer screens such that all firms and all workers see all wage offers. Wage offers are ordered from high to low, but offers are anonymous. That is, a particular wage offer cannot be related to a particular firm. In the second stage, each worker can at most accept one wage offer. Workers are randomly arrayed in a queue and can choose from the remaining offers. Workers who have accepted an offer choose an effort $e=\{1, . ., 10\}$.

At the end of each period, all participants are shown an outcome screen summarizing the interaction results of the current period and of all previous periods. In particular, each participant obtains information about the accepted wage, the effort provided and the corresponding earnings in one's own firm-worker pair, as well as about the average market wage.

Monetary payoffs depend on the tax regime. In both regimes, a specific tax of $T A X=20$ is levied on each transaction. If the tax is levied on firms (ToF) payoffs in case a wage offer is accepted are:
(1) For firms:
$\pi=30-W+10 e-T A X$
(2) For workers:
$U=W-e$

If the tax is levied on workers (ToW) payoffs in case a wage offer is accepted are:
(3) For firms:
$\pi=30-W+10 e$
(4) For workers:
$U=W-e-T A X$ 
Workers who do not accept an offer get a payoff of $U_{0}=4$ points (the reservation wage), and firms who do not hire a worker get zero profit $\left(\pi_{0}=0\right){ }^{2}$

Written instructions (see appendix A) are distributed before each phase, and subjects have to correctly answer a series of control questions at the beginning of a new phase. At the beginning of phase 1 , subjects are informed that phase 1 has 16 periods, and subjects know that there is going to be a second phase. However, subjects do not know at the beginning of phase 1 the proceedings of phase 2 . In particular, they do not know that the other market side will be taxed in phase 2. Subjects are provided with a pocket calculator during the experiment. In the instructions, we use a neutral wording. In particular, instructions speak of buyers (firms), sellers (workers), price (wage) and quality (effort). However, the tax is simply called tax.

As in FKR (1993), all markets had an excess supply of at least 40 percent (there were either 7 workers and 5 firms or 6 workers and 4 firms). Therefore, at least 2 workers remain unemployed in each period. We chose this considerable excess supply to make the market competitive. Since we are particularly interested in short-run and long-run adjustment of wages and market rents we run each tax regime for 16 periods (stationary replication).

Our design differs from FKR (1993) in two respects. First, we use linear payoff functions (as in Brandts and Charness 2000). Our parametrization involves relatively large potential gains from gift exchange which is known to forward effciency wage characteristics (see Hannan et al. 2002, Engelmann and Ortmann 2002). Note that providing a higher effort increases firm profits (by 10 points per unit) but is costly ( 1 point per unit) to workers.

The second and crucial difference to FKR (1993) is that our design involves taxation. We use a specific transaction tax because specific taxes are cognitively easier to understand and to implement than ad valorem taxes. For example, since ad valorem taxes depend on the value (and hence the wage) of the transaction, one needs to impose two different tax rates in the two regimes for tax LSE to hold in theory. Note that by holding the range of admissible posted wages $W$ constant (at 1 to 100 ), the range of admissible net wages $w$ (i.e., after-tax

\footnotetext{
2 A firm also earns zero profits if its wage offer was accepted but the worker provided an effort which would have resulted in a loss for the firm. We implement this stop-loss condition because it makes offering high wages less risky for the firm and tends to induce higher wages. The reason is that if firms are loss-averse (Kahneman and Tversky 1991), they are reluctant to offer wages that would result in losses in the event workers choose low efforts. Hence, the stop-loss condition tends to induce higher average wages, and it is crucial that wages are sufficiently high in order to be able to test tax LSE in gift-exchange efficiency-wage markets.
} 
wages) is different in the two tax regimes. That is, the net wage is $w=W-T A X$ in ToW, but is $w=W$ in ToF. As a consequence, $w$ is in the range 1 to 100 in the regime ToF, but is in the range -20 to 80 in ToW. The reason we decided to hold the range of admissible posted wages constant is to avoid a possible experimenter demand effect. Changing the range of admissible posted wages may, for example, induce the belief among firms that we (the experimenters) expect them to post lower wages, and among workers that we expect them to accept lower wages in ToF.

\subsection{Predictions and hypotheses}

To derive the theoretical predictions under the standard assumptions of fully rational agents who are strictly interested in their own material well-being, we proceed by backward induction. In the second stage of the game, a worker will never provide effort above the minimum level $\underline{e}=1$ because it is costly to do so. Note that there are no long-term considerations, like reputation formation, to be taken into account because of the anonymity of market interaction. In equilibrium workers accept any net wage offer of at least $w_{0}=5$ because this guarantees earnings of at least $U_{0}=4$. In the first stage, firms anticipate workers' second-stage behavior and offer $\underline{w}=5$, the lowest possible net wage inducing workers to accept. Hence, given the standard assumptions, the equilibrium prediction is a net wage $\underline{w}=5$ and an effort level $\underline{e}=1$.

In ToF, the firm has to pay a specific tax of $T A X=20$ units and the wage paid by the firm is equal to the net wage. This results in an equilibrium profit of $\underline{\pi}=30-\underline{w}+10 \underline{e}-20=$ 15 for the firm and an equilibrium payoff of $\underline{U}=\underline{w}-\underline{e}=4$ for an employed worker. According to tax LSE, the predictions are exactly the same in case the worker has to pay the specific tax (ToW), except that the wage paid by the firm is now a gross wage $W_{0}($ ToW $)=25$.

However, theoretical considerations based on Akerlof (1982) and the experimental evidence in other gift-exchange markets (FKR 1993, 1998, Fehr, Kirchler, Weichbold, and Gächter 1998, Brandts and Charness 2000) leads us to expect efficiency wages $w^{*}>w_{0}$ and a positive relation between net wages and efforts provided [de/dw>0]. Consequently, we hypothesize that employed workers and firms earn rents $U^{*}>U_{0}$ and $\pi^{*}>\pi_{0}$, respectively. These predictions depend on subjects' willingness to give and reciprocate gifts. Since the actual intensity of this willingness is not known ex ante, it is impossible to provide point predictions for $w^{*}, e^{*}$, and rents. The qualitative relationships are clear and testable, however. 
Additionaly, as long as workers base their effort decisions only on the net wage, tax LSE should still hold.

In both tax regimes firms post a wage $W$. From the perspective of the workers this wage is a net wage in ToF, but a gross wage in ToW. Assume now that workers' effort choices do not exclusively depend on the net wage but also on the gross wage. If this holds, a reduction of the (gross) wage offered by the firm leads to a reduction in effort provided. Therefore, the alternative hypothesis holds that tax shifting will only be partial to the effect that the tax tends to "stick where it hits".

To illustrate this partial tax shifting hypothesis, consider the case of a change in taxation from ToW to ToF. According to tax LSE, wages paid should fall by the extent of the tax such that workers obtain the same net wage as before. However, suppose the workers obtained a rent, and suppose workers feel entitled to a particular gross wage. Then, firms anticipating this reaction, expect that workers reduce their efforts in response to reduced gross wages. As a consequence, firms will continue to pay relatively high gross wages. If this reasoning holds, net wages increase in response to a change in the tax regime from ToW to ToF. Conversely, net wages fall in response to a change in taxation from ToF to ToW.

We summarize the above discussion as follows. Assume that workers are reciprocal in the sense that they react with higher effort levels on higher wages and - for the sake of simplicity - that firms are profit maximizers and that they know the wage-effort relationship. To derive our null hypothesis that tax LSE holds, we assume that both sides of the market base their decisions on net values. It then holds: $w^{\text {net }}(\mathrm{ToF})=w^{\text {net }}(\mathrm{ToW})=w^{*} \geq w_{0}$; $e\left[w^{\text {net }}(\mathrm{ToF})\right]=e\left[w^{\text {net }}(\mathrm{ToW})\right]=e^{*} \geq \underline{e} ;$ this implies $U(\mathrm{ToF})=U(\mathrm{ToW})=U^{*} \geq U_{0} ; \pi(\mathrm{ToF})=$ $\pi(\mathrm{ToW})=\pi^{*} \geq \pi_{0}$. Importantly, the after-tax distribution of income is the same in both tax regimes. Alternatively, assume now that workers at least partly base their effort decision on the wage paid by the firm. It then holds: $w^{\text {net }}(\mathrm{ToF})>w^{\text {net }}(\mathrm{ToW}) \geq w_{0}$ and $w^{\text {net }}(\mathrm{ToF}) \leq$ $w^{\text {gross }}(\mathrm{ToW})$ which implies $e\left[w^{\text {net }}(\mathrm{ToF})\right] \leq e\left[w^{\text {gross }}(\mathrm{ToW})\right] ; U(\mathrm{ToF})>U(\mathrm{ToW}) \geq U_{0} ; \pi(\mathrm{ToW})$ $>\pi(\mathrm{ToF}) \geq \pi_{0}$. 


\section{Results}

We conducted 6 markets in treatment ToF/ToW and 6 markets in treatment ToW/ToF in the computerized CREED laboratory at the University of Amsterdam. In total, 136 undergraduate students from various disciplines participated in our experiment. Each subject only participated in one treatment. Subjects earned $€ 29.70$ (US\$ 30, approx.) on average in about 130 minutes. Section 4.1 presents the main results, section 4.2 discusses the effect of taxation on net wages in detail, and section 4.3 explains how taxation affected workers' and firms' rents.

\subsection{Main results}

Our first main result is that the experimental markets under study in general do exhibit pronounced and stable efficiency wage characteristics. That is, net wages are clearly above reservation wages, efforts are above the minimum level, efforts are positively related to wages, and both workers and firms earn rents. To show that this is the case, we now take a broad look at the markets in the two tax regimes. In this section, we aggregate observations over all periods and both phases of each regime, and analyze more disaggregated data in the sections below (see appendix B for data from individual markets).

First, net wages are far above the reservation wage $\left(w_{0}=5\right)$ in both tax regimes. In fact, net wages (averaged over all markets, periods and phases) are 48.2 if the tax is on firms (ToF), and 45.7 if the tax is on workers (ToW). Second, average efforts are clearly above the minimum level $(\underline{e}=1)$ in both tax regimes. In particular, efforts (again averaged over all markets, periods and phases) are 5.4 in ToF and 5.2 in ToW. Third, there is a clear positive relation between the efforts provided and the net wages. Figure 1 provides support for this claim. The figure shows average efforts for different ranges of average net wages in the two tax regimes. The figure indicates, for example, that average efforts in contracts in which the net wage is below 20 was only 1.3 in both tax regimes (see leftmost bars). In contrast, if the net wage is above 60 the average effort is 7.5 if ToF and 7.6 in ToW (see rightmost bars).

Fourth, workers and firms earn rents as a consequence of these pronounced efficiency wage market characteristics. Employed workers have average net earnings of 42.2 in ToF and of 39.8 in ToW, which is far above the workers' outside option $\left(U_{0}=5\right)$. Firms pay efficiency 
wages because it is profitable for them to do so. In particular, average profits are 22.1 in ToF, and 22.4 in ToW. This is above what firms would have earned in the absence of the giftexchange relation $\left(\pi_{0}=15\right)$.

Figure 1: Relation of efforts and net wages in the two tax regimes

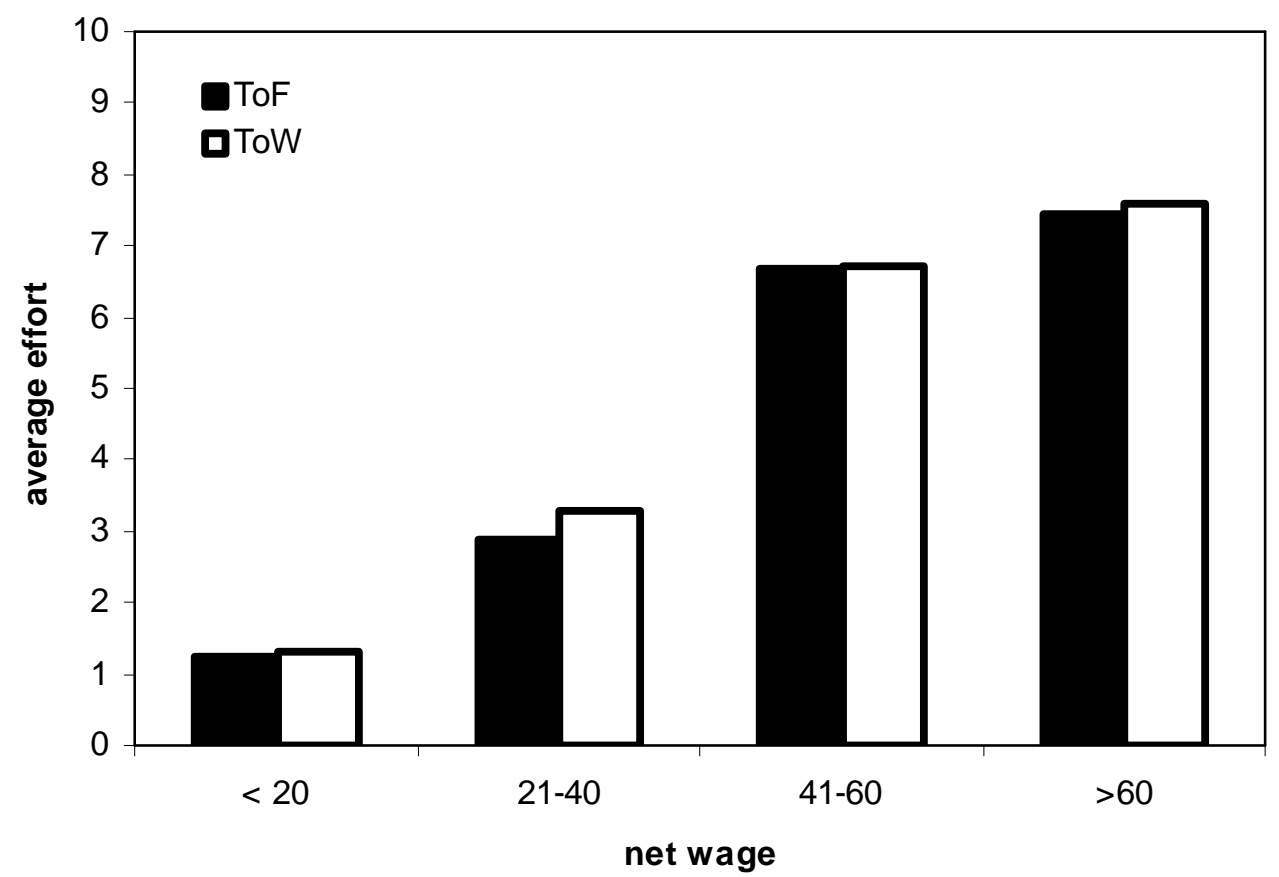

Taken together, these results clearly indicate that our parametrization creates ideal preconditions to test tax LSE in gift-exchange markets since the markets under investigation do indeed exhibit pronounced efficiency-wage characteristics. At the same time, the discussion above also provides a first indication for the main result of this study that $\operatorname{tax} L S E$ holds very well in the efficiency wage market. Whether the tax is levied on the firms or the workers does neither seem to substantially affect average net wages, nor efforts, nor the relation between the two (see also figure 1).

\subsection{Testing net wages for tax LSE}

In this section, we test net wages for tax LSE along three dimensions. It will be shown that tax LSE impressively holds for net wages (i) across subjects, (ii) within subjects even on impact, and (iii) that tax LSE is robust with respect to sequencing effects. 
Figure 2 shows net wages (i.e., after-tax wages) averaged over all sessions in the respective treatments over time (see appendix B for disaggregated data). The thin line shows the evolution of average net wages in ToF/ToW and the thick line indicates the same time series for ToW/ToF. Consider first tax LSE across subjects. As can be seen, average net wages are almost perfectly the same already in period 1 of phase 1 irrespective of whether the tax is levied on firms (41.2) or on workers (42.7). Net wages remain fairly stable throughout the first phase of the experiment (periods 1-16). While net wages averaged over the entire first phase are somewhat higher if firms are taxed (48.8) than if workers are taxed (42.3), there is no statistical difference in any single period between ToF and ToW (Mann-Whitney tests, $p>$ 0.24 for each period) or over all periods jointly (Mann-Whitney test, $p=0.70$ ), when taking the average market wage as a unit of observation.

Figure 2: Average net wages over time

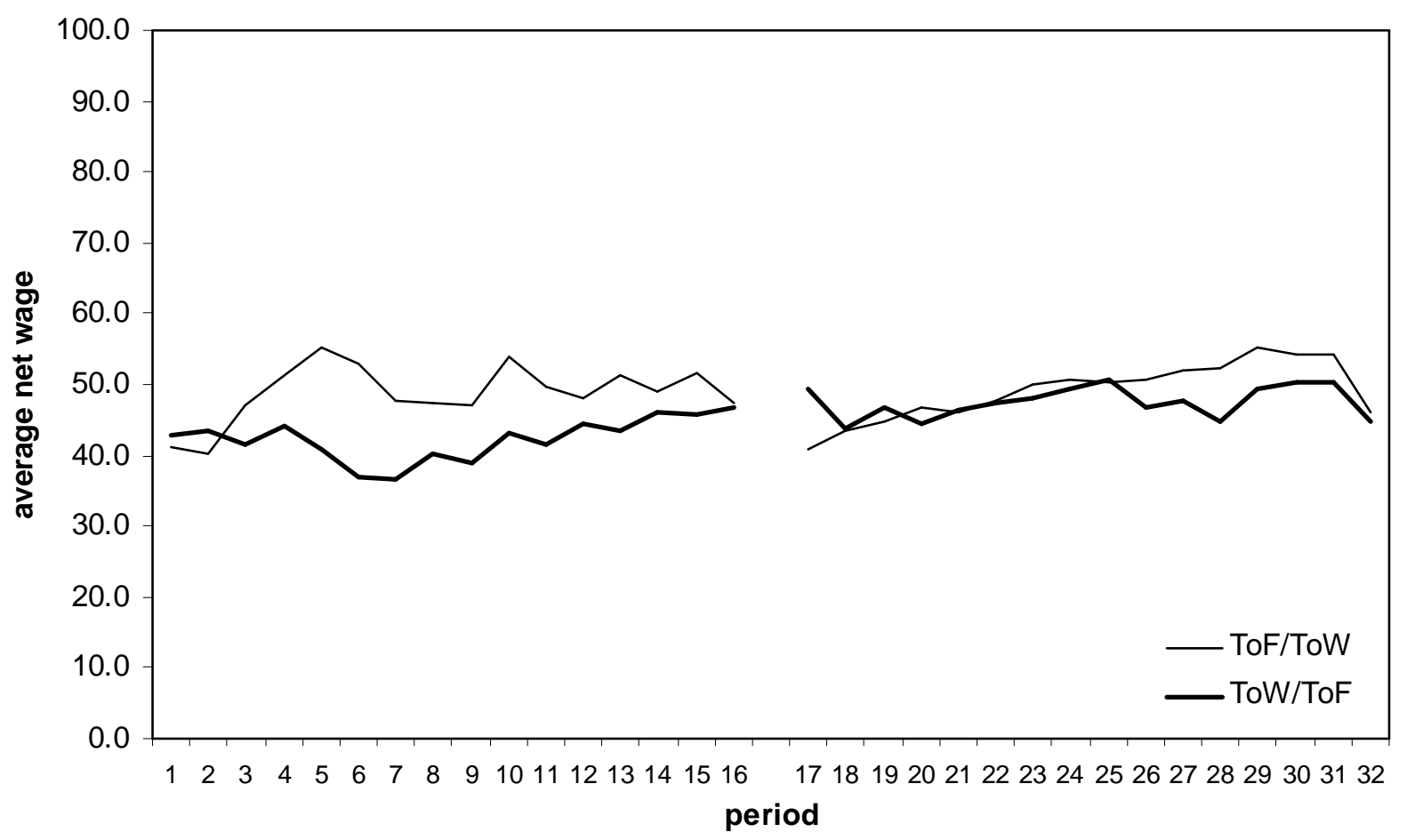

The same picture emerges if we compare across treatments in phase 2 (periods 17-32). Averaged over all periods of phase 2, net wages are now slightly lower if firms are taxed (47.5), than if workers are taxed (49.1). However, average net wages are not statistically different in a period-by-period comparison (Mann-Whitney tests, $p>0.24$ ) or in a comparison 
over all periods jointly (Mann-Whitney test, $p=0.70$ ). We conclude that net wages were the same in the two treatments for across-treatment comparisons, holding experience with the market institution constant (comparison of tax regimes in a given column of tables 1 and 2).

Table 2: Summary of results

\begin{tabular}{|c|c|c|c|c|}
\hline & & $\begin{array}{l}\text { Phase 1 } \\
\text { (Averages over } \\
\text { all markets, } \\
\text { periods 1-16) }\end{array}$ & $\begin{array}{c}\text { Phase } 2 \\
\text { (Averages over } \\
\text { all markets, } \\
\text { periods 17-32) }\end{array}$ & $\begin{array}{c}p \text {-values for Wilcoxon } \\
\text { tests, comparisons } \\
\text { within treatments }\end{array}$ \\
\hline $\begin{array}{l}\text { Treatment } \\
\text { ToF/ToW }\end{array}$ & $\begin{array}{l}\text { net wage: } \\
\text { effort: } \\
\text { worker earnings } \\
\text { firm profits }\end{array}$ & $\begin{array}{r}48.8 \\
5.6 \\
42.6 \\
21.9\end{array}$ & $\begin{array}{r}49.1 \\
5.7 \\
42.7 \\
23.5\end{array}$ & $\begin{array}{l}0.70 \\
0.53 \\
0.92 \\
0.25\end{array}$ \\
\hline $\begin{array}{l}\text { Treatment } \\
\text { ToW/ToF }\end{array}$ & $\begin{array}{l}\text { net wage: } \\
\text { effort: } \\
\text { worker earnings } \\
\text { firm profits }\end{array}$ & $\begin{array}{r}42.3 \\
4.8 \\
36.9 \\
21.4\end{array}$ & $\begin{array}{r}47.5 \\
5.1 \\
41.9 \\
22.2\end{array}$ & $\begin{array}{l}0.17 \\
0.46 \\
0.17 \\
0.60\end{array}$ \\
\hline $\begin{array}{l}p \text {-values for Mann- } \\
\text { Whitney tests, } \\
\text { comparisons across } \\
\text { treatments }\end{array}$ & $\begin{array}{l}\text { net wage: } \\
\text { effort: } \\
\text { worker earnings } \\
\text { firm profits }\end{array}$ & $\begin{array}{l}0.70 \\
0.39 \\
0.59 \\
0.82\end{array}$ & $\begin{array}{l}0.70 \\
1.00 \\
0.70 \\
0.82\end{array}$ & $\begin{array}{l}\text { F/W: } 0.35, W / F: 0.75 \\
\text { F/W: } 0.46, W / F: 0.35 \\
\text { F/W: } 0.21, W / F: 0.60 \\
\text { F/W: } 0.25, W / F: 0.25\end{array}$ \\
\hline
\end{tabular}

Note: All tests are two-sided and take market averages as the unit of observation. The lower right cell tests for short-run effects by comparing market averages in period 16 and 17 within treatments. F/W shows the $p$ value of Wilcoxon tests for a change of taxation from firms to workers (treatment ToF/ToW), W/F the corresponding value for a change of taxation from workers to firms.

Second, we test tax LSE within subjects across different tax regimes (comparison of regimes in a given row in tables 1 and 2). There are no significant differences when comparing the two tax regimes period by period (e.g., period $1,2, \ldots$ in ToF/ToW with period $17,18, \ldots$ in $\mathrm{ToF} / \mathrm{ToW}$ ) in both conditions ${ }^{3}$ or if we compare all periods jointly (Wilcoxon tests, ToF/ToW $p=0.75$, ToW/ToF $p=0.17$, see rightmost column of table 2). Tax LSE even holds on impact after a change in the tax regime. Tax LSE predicts that net wages should not change in a market if taxation is changed from workers to firms, or vice versa. In contrast, the

3 The single exception is period 6 in ToW(1) with period 22 in ToW(2), which is weakly significant $p=0.04$ according to a Wilcoxon test. The two next lowest $p$-values are $p=0.17$ for periods $9 / 25$ in ToF, and $p=0.22$ for periods $7 / 23$ in ToW. All other $p$-values are larger than 0.25 . 
partial shifting hypothesis holds that net wages should fall when workers instead of firms are taxed, and vice versa. In line with this partial shifting hypothesis, net wages indeed do fall (from 47.5 to $40.8,-14.0$ percent) when the workers instead of the firms are taxed (compare periods 16 and 17 in figure 2, thin line), and net wages slightly increase (from 46.7 to 49.2, +5.4 percent) when taxation is shifted from the firms to the workers. However, these impact effects are not statistically significant. The hypothesis that average net wages are the same in periods 16 and 17 cannot be rejected for either change in tax regime (Wilcoxon tests, for ToF/ToW $p=0.35$, for ToW/ToF $p=0.75)$.

Third, efficiency wages are rather stable throughout the experiment, and there are no significant effects of sequencing. In particular, average net wages are not different for a given tax regime across phases according to Mann-Whitney tests (ToF(1) vs. $\operatorname{ToF}(2): p=0.39$, ToW(1) vs. ToW(2): $p=0.49)$. Comparing each of the corresponding periods yields no significant differences either [e.g., period 1 in ToF(1) with period 17 in ToF(2)]. In both tax regimes there is no $p<0.24$ in any comparison (Mann-Whitney tests).

\subsection{Testing rents for tax LSE}

Tax LSE implies that the post-tax distribution of rents is the same irrespective of which side of the market is taxed. In this section, we test rents for tax LSE along the same three dimensions as for net wages in the previous section. We refrain from an extensive discussion of effort choices to save on space and because, given the wage, effort choices linearly translate into worker earnings and firm profits. Since we have already shown in the previous section that tax LSE holds with respect to net wages, and since this section is going to demonstrate that tax LSE also holds with respect to rents, the reader should be easy to convince that tax LSE also holds with respect to effort choices. Table 2 shows in detail that efforts were not statistically different in any of the three dimensions under consideration.

Figure 3 shows average earnings for workers (broken lines) and average firm profits (solid lines) over time for agents who trade. Worker earnings seem higher in both tax regimes throughout all periods. Note, however, that in the figure in each period (at least two) workers are excluded who only earn their outside option. The reason for excluding these workers is that tax LSE is only predicted to hold for transactions. 
Figure 3: Average firm profits and hired worker earnings

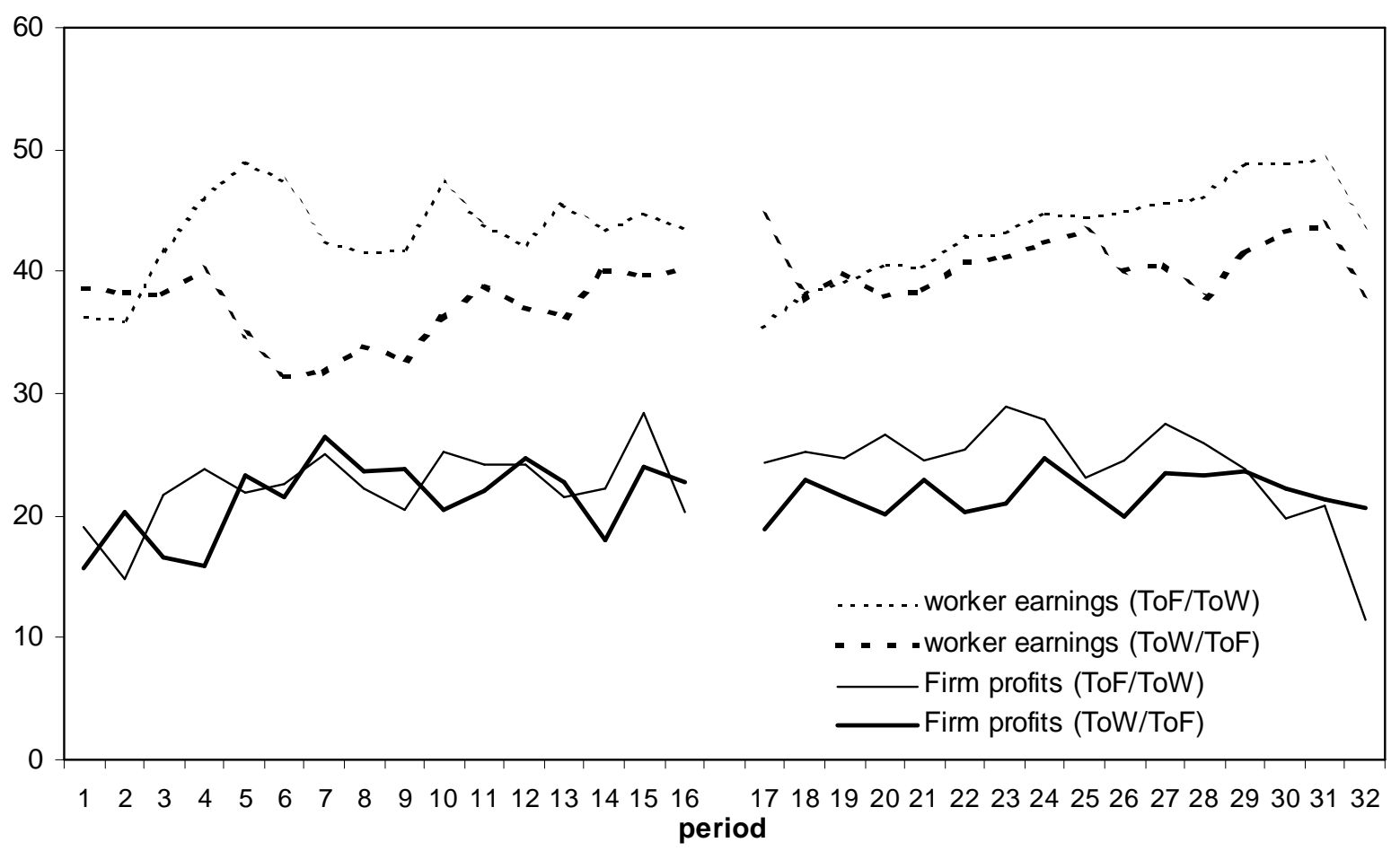

First, tax LSE holds for workers' earnings in an across-treatments comparison. In period 1, worker earnings are very similar in an across-subjects comparison (36.4 in ToF, 39.0 in ToW). Figure 3 seems to indicate that, along with the partial tax-shifting hypothesis, worker earnings are higher if firms are taxed throughout the first phase. However, the differences are statistically not significant; neither in a period-by-period comparison (Mann-Whitney tests, $p$ $>0.13$ in each period), nor when considering all periods jointly (Mann-Whitney test, $p=$ 0.59). In the second phase, worker earnings are very similar in the two tax conditions (no significant differences period by period $p>0.18$, all periods jointly $p=0.70$, see table 2 ). Second, a within-treatment comparison yields the same conclusion with respect to a change of taxation. Average worker earnings fall from 42.3 in period 16 to 35.5 in period 17 in the regime change ToF/ToW (see fine dotted line), and increase from 41.7 to 44.0 in the regime change ToW/ToF (see heavy dotted line). However, these differences are not significant according to a Wilcoxon test (ToF/ToW $p=0.21$, ToW/ToF $p=0.60)$. Third, there is no significant effect of sequencing (Mann-Whitey tests, ToF $p=0.49$, ToW $p=0.59$ ).

In summary, we conclude that tax LSE holds with respect to worker earnings. This result is in line with the evidence on net wages presented in section 4.1. The reason is that net wages tend to affect worker earnings much more than effort choices because wages can vary from 1 to 100, while efforts can only vary from 1 to 10 . 
Firm profits are much more sensitive to effort choices than worker earnings. In particular, a marginal change in effort choice affects worker earnings by 1 unit while it affects firm profits by 10 units. Despite this fact, firm profits are neither different in an acrosstreatment comparison, nor in a within-treatment comparison, nor are there any sequencing effects. For example, firm profits are very similar in the first period of the experiment in both regimes (19.1 in ToF, 15.9 in ToW), and the same holds throughout all periods of the experiment, irrespective of the tax regime. In fact, there are no significant differences in an across-treatment comparison for any single period (Mann-Whitney tests, $p>0.13$ ) or for all periods of phase 1 jointly (Mann-Whitney test, $p=0.82$ ). The same holds for phase 2 (MannWhitney tests, each period $p>0.09$, all periods jointly $p=0.82$ ). Furthermore, there are no significant differences in a within-treatments comparison, neither are there significant sequencing effects (see table 2).

In all, we conclude that the rent distribution is fairly stable throughout the experiment, and that rents are unaffected by the tax regime.

\section{Concluding remarks}

Tax LSE is a fundamental proposition of economics. It claims that who bears the tax burden (economic incidence) is independent of who legally pays the tax (statutory incidence). Standard theory suggests that tax LSE holds in gift-exchange markets as long as workers make their effort choices exclusively dependent on net wages. However, if workers make their effort provision contingent on wages paid by firms, and consider taxation as exogenous to the job relation, tax LSE breaks down.

We implement a gift-exchange market known to exhibit pronounced efficiency-wage characteristics, and impose a specific tax either on workers or on firms. We test tax LSE along three dimensions. We find that tax LSE holds surprisingly well across treatments, within treatments, and even on impact after a change in the tax regime. Net wages are not different whether we compare independent markets which only differ with respect to the tax regime, whether we compare two tax regimes in a given market, or whether we analyze the impact effect of a change of the tax regime in a market. Furthermore, we find no effects of 
sequencing. The same holds for efforts and the post-tax distribution of rents for workers and firms.

Despite the surprising clarity of our experimental results we would not like to interpret our finding as implying that it never matters how, for example, social security contributions are assessed in labor markets for at least four reasons. First, we find that tax LSE holds in a fairly competitive gift-exchange market with an excess supply of 40 percent. Whether actual labor markets in the field are as competitive as that or whether (in particular collective) bargaining elements are more important depends on the actual market under consideration. Second, we did not allow for long-term relations between workers and firms in our experiment. However, such relations are quite typical in naturally occurring labor markets. Since long-term relations have been shown to cause price rigidity in experimental markets with quality uncertainty (Renner and Tyran 2003), it is likely that long-term relations also affect tax LSE. Third, information about the tax regime was public in our experiment. In particular, both firms and workers knew that firms had to pay the tax. One may speculate that if information is private, i.e., if only firms know about the tax, there may be less acceptance for falling gross wages, and the alternative hypothesis may have more explanatory power in this case. Finally, statutory incidence results from a political process. Political decisionmakers have to form expectations about the effects of taxing one or the other side of the market, and make the collective decision according to their expectations. If some political decision-makers are prone to tax illusion, some taxes may have higher political acceptance than others (Sausgruber and Tyran 2002).

Our finding that tax LSE holds in gift-exchange markets is novel and surprising in our view. While previous experimental studies have shown that tax LSE holds in competitive goods markets, tax LSE has also been shown to clearly fail in a bargaining experiment in which fairness considerations are paramount. Given that fairness considerations are known to be important in the gift-exchange labor market we study, one might legitimately expect that tax LSE does not hold at least in the short run, and that market forces may eventually drive net wages towards tax LSE over time, if at all. Yet, we find that the "most basic theorem of public finance" holds even in the short run in gift-exchange markets. 


\section{References}

Akerlof, G.A. (1982): Labor Contracts as Partial Gift Exchange. Quarterly Journal of Economics 97(4): 543-69.

Bewley, T.F. (1999): Why Wages Don't Fall During a Recession. Cambridge: Harvard University Press.

Blinder, A.S. (1988): The Challenge of High Unemplyoment. American Economic Review 78(2): 1-15.

Borck, R. Engelmann, D., Müller, W. and Normann, H.-T. (2002): Tax Liability Side Equivalence in Experimental Posted Offer Markets. Southern Economic Journal 68(3): $672-82$.

Brandts, J. and Charness, G. (2003): Do Labour Market Conditions Affect Gift Exchange? Some Experimental Evidence. Working paper, July 2003. Forthcoming in Economic Journal.

Camerer, C.F. (2003): Behavioral Game Theory: Experiments in Strategic Interaction. Princeton University Press: Princeton.

Campbell, C.S. and Kamlani, K.S. (1997) The Reasons for Wage Rigidity: Evidence from a Survey of Firms. Quarterly Journal of Economics 112(3): 759-89.

Dalton, H. (1922): Principles of Public Finance. London.

Engelmann, D. and Ortmann, A. (2002): The Robustness of Gift Exchange: An Experimental Investiation. Working paper CERGE-EI, Prague, September 2002.

Fehr, E. and Gächter, S. (2000): Fairness and Retaliation: The Economics of Reciprocity. Journal of Economic Perspectives 14(3): 159-81.

Fehr, E., Kirchler, E., Weichbold, A. and Gächter, S. (1998): When Social Norms Overpower Competition. Gift Exchange in Experimental Markets. Journal of Labor Economics 16(2): 321-54.

Fehr, E., Kirchsteiger, G. and Riedl, A. (1993): Does Fairness Prevent Market Clearing? An Experimental Investigation. Quarterly Journal of Economics 108(2): 437-59.

Fehr, E., Kirchsteiger, G. and Riedl, A. (1998): Gift Exchange and Reciprocity in Competitive Experimental Markets. European Economic Review 42(1): 1-34. 
Fullerton, D. and Metcalf, G. (2003, eds.): The Distribution of Tax Burdens. Cheltenham, UK: Edward Elgar.

Güth, W., Schmittberger, R. and Schwarze, B. (1982). An Experimental Analysis of Ultimatum Bargaining. Journal of Economic Behavior and Organization 3(4): 367-88.

Hannan, L.R., Kagel, J.H. and Moser, D.V. (2002): Partial Gift Exchange in an Experimental Labor Market: Impact of Subject Population Differences, Productivity Differences, and Effort Requests on Behavior. Journal of Labor Economics 20(4): 923-51.

Kachelmeier, S.J., Limberg, S.T. and Schadewald, M.S. (1994): Experimental Evidence of Market Reactions to New Consumption Taxes. Contemporary Accounting Research 10(2): 505-45.

Kahneman, D. and Tversky, A. (1991): Loss Aversion in Riskless Choice: A ReferenceDependent Model. Quarterly Journal of Economics 106(4): 1039-61.

Kerschbamer, R. and Kirchsteiger, G. (2000): Theoretically Robust but Empirically Invalid? An Experimental Investigation into Tax Equivalence. Economic Theory 16(3): 719-34.

Lockwood, B. and Manning, A. (1993): Wage Setting and the Tax System. Theory and Evidence for the United Kingdom. Journal of Public Economics 52(1): 1-29.

Musgrave, R. (1959): The Theory of Public Finance. New York: McGraw-Hill.

OECD (2000): Economic Surveys - Poland. Electronic Edition, Annex II.

Picard, P.M. and Toulemonde, E. (2001): On the Equivalence of Taxes Paid by Employers and Employees. Scottish Journal of Political Economy 48(4): 461-70.

Pisauro, G. (1991): The Effect of Taxes on Labour in Efficiency Wage Models. Journal of Public Economics 46(3): 329-45.

Renner, E. and Tyran, J.-R. (2003): Price Rigidity in Customer Markets. Working paper University of St. Gallen, May 2003.

Ruffle, B.J. (2001): Tax and Subsidy Incidence Equivalence Theories: Experimental Evidence from Competitive Markets. Working paper Ben-Gurion University, October 2001.

Sausgruber, R. and Tyran, J.-R. (2002): Testing the Mill Hypothesis of Fiscal Illusion. mimeo, Univ. of St. Gallen.

Stiglitz, J.E. (1988): Economics of the Public Sector, 2nd ed. Norton: New York. 


\section{Appendix A: Instructions}

Translated from Dutch. Parts in italic are not part of the original instructions.

\section{General instructions for all participants (all treatments, all subjects)}

You are now participating in an experiment on decision-making in markets. The instructions are simple and if you read them carefully you can earn money. During the experiment we use the "token" as currency unit. At the end of the experiment all tokens you have earned will be converted to Euros according to the exchange rate 1 token $=3$ Eurocent.

The experiment consists of two parts. In each part all participants receive an initial endowment of $\mathbf{7 5}$ tokens. Depending on your role in the experiment, losses are possible in principle, but can always be avoided by your own decisions.

You are now receiving instructions for part 1. When the first part of the experiment has ended you receive the instructions for part 2.

\section{Instructions for part 1}

Here is a short summary of the first part of the experiment, a more extensive description follows later. In this experiment there are buyers and sellers. Shortly you are informed which role you will have during the whole experiment. In the experiment buyers and sellers can earn income by trading a hypothetical good. The experiment consists of one practice round and $\mathbf{1 6}$ trading days. The practice round will not be paid. We advise you to nevertheless take the practice round serious. Each trading day consists of three phases.

In the first phase each buyer can make a price bid that indicates that he or she is ready to buy the good at that price. Each buyer can make at most one bid.

In the second phase sellers can sequentially - in a randomly determined sequence - choose from the bids made. Each seller can accept at most one offer.

In the third phase each seller who has accepted an offer has to determine the quality of the good. A higher quality means that the seller has higher costs and that the buyer receives a higher income. After a seller has determined the quality his/her buyer is informed about the quality chosen. With that a trading day ends.

Neither the seller nor the buyer receives information about the identity of his/her trading partner. Since sellers choose which offers to accept, they are, in general, matched with different buyers in different rounds.

In each trading day each seller can at most sell one unit of the good and each buyer can at most buy one unit of the good. There are more sellers than buyers in the market. Thus, some sellers will not be able to trade.

During the whole experiment you are not allowed to communicate with other participants by any means.

If you have questions please raise your hand. An experimenter will come to you to answer your question. If you do not have any questions click on the button $\langle\operatorname{KLAAR}\rangle(\langle R E A D Y\rangle)$ and wait for further instructions. 


\section{Specific instructions for sellers (Treatment ToF/ToW)}

You are a seller during the whole experiment. By selling a good on the market you can earn tokens. Each seller can sell to each buyer and each buyer can buy from each seller, in principle. Each seller and each buyer can trade at most one good per trading day.

Each trading day on the market consists of three phases, which are organized as follows:

First phase:

At the beginning of a trading day buyers can make a bid. Buyers can also choose not to make a bid. Each buyer can make at most one bid. A bid is a price at which a buyer is willing to buy. A bid is binding, that is, it cannot be revoked. The bid has to be in the interval from 1 to 100. Only integers are allowed. When a seller accepts a bid this is the amount the buyer pays for the good.

While the buyers decide about their price bids you have to indicate your expectation on the average bid. It is important that you state your true expectations. Therefore, we ask you to think carefully before you make your decision.

Second phase:

The bids are shown on the computer screens of all buyers and sellers in descending order. The computer determines the sequence in which sellers can choose from the bids randomly. Each seller can accept at most one bid. A seller can also choose not to accept any bid. The first seller in the sequence can choose from all bids, the second from the remaining bids and so on. This procedure ends if all sellers had the opportunity to choose or if all bids are accepted. Since there are more sellers than buyers not all sellers will be able to sell a good.

Third phase:

If you have accepted a bid you have to decide which quality you deliver. There are ten different quality levels from which you can choose. The lowest quality is $\mathbf{1}$ and the highest quality is 10. Only integer values are allowed. The higher the quality you choose the higher are your costs and the higher are the earnings of the buyer. The enclosed summary sheet shows the costs that are associated with each quality level. The relation between quality and costs is the same for all sellers and all buyers are informed about this relation.

Remark: all decisions are anonymous, that means that nobody is informed about the identity of the person that makes a decision. For instance, a buyer is informed whether his or her bid is accepted, but receives no information about who of the sellers has the bid accepted/rejected.

Note: For each good bought buyers have to pay a tax of 20 tokens.

At the end of a trading day the following outcomes are possible:

1. You have not sold a unit of the good. In this case your earnings in this trading day are 4 tokens.

2. You sold a unit. In this case your earnings in this trading day are:

Your earnings from trading $($ in tokens $)=$ price - quality costs.

The earnings from trading of the buyer are:

Earnings from trading of the buyer (in tokens $)=30+(10 \times$ quality $)-$ price - tax of 20 ,

or 0 tokens if this should be negative. 
Note: A buyer who buys nothing earns 0 tokens.

At the end of a trading day 'your' buyer receives information about your 'earnings from trading' and you receive information about the 'earnings from trading' of 'your' buyer.

The computer screen you will see shortly consists of 4 parts:

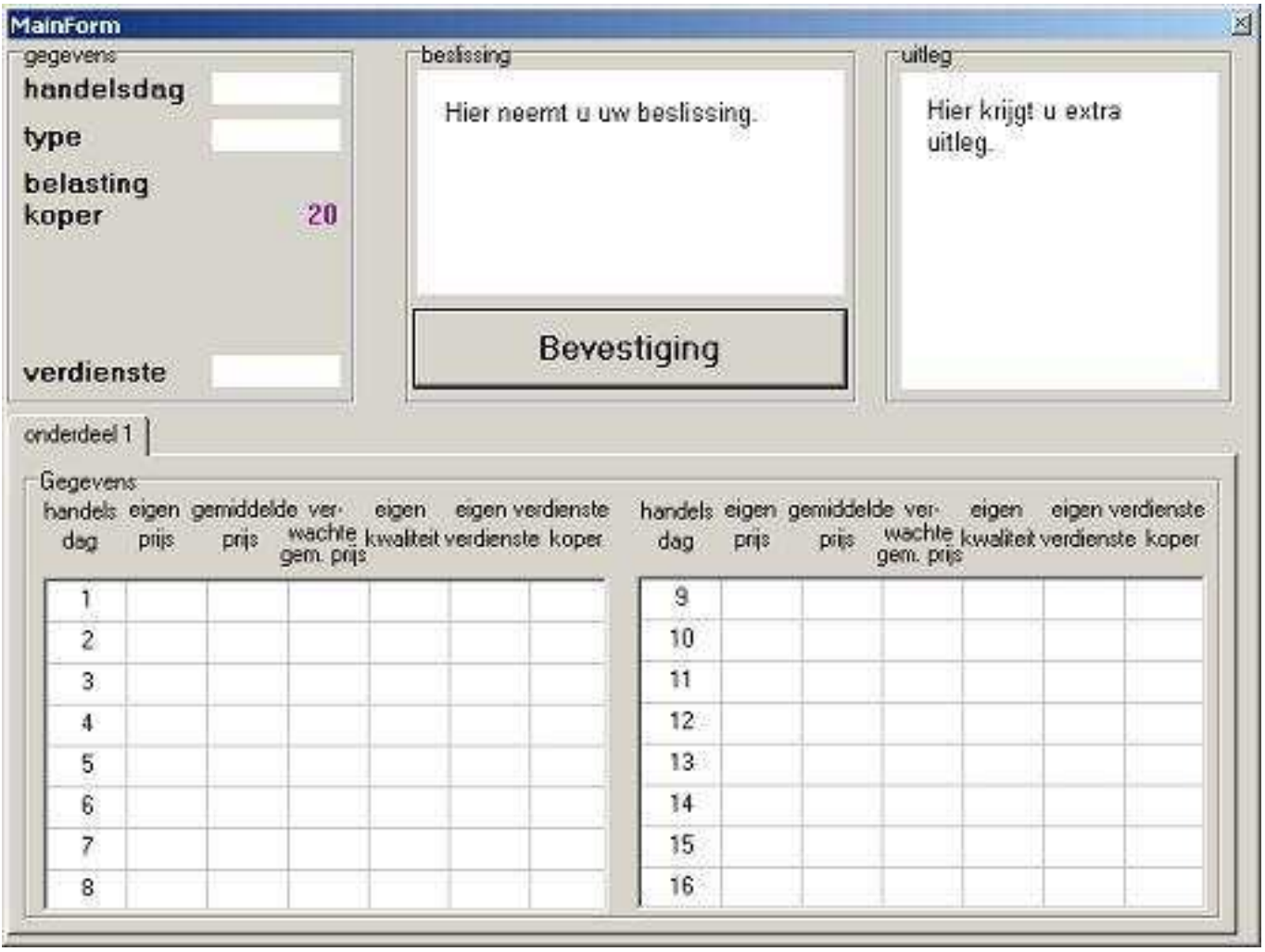

In the upper left part you see your type (in your case 'seller'), information about the tax, the current trading day and your 'total income' from the previous trading days.

In the upper right part you receive an explanation about the decision you have to make.

In the upper middle part you take your decision. When you have made your decision you have to confirm it by clicking on the button 'Bevestiging' ('confirmation') with the help of the mouse.

In the lower part you receive a summary of the results on each trading day.

If you have a question now, please raise your hand.

If you do not have any questions any more please click on $\langle$ KLAAR $\rangle(\langle R E A D Y\rangle)$ and wait for further instructions. 


\section{Specific instructions for buyers (Treatment ToF/ToW)}

You are a buyer during the whole experiment. By buying a good on the market you can earn tokens. Each buyer can buy from each seller and each seller can sell to each buyer, in principle. Each seller and each buyer can trade at most one unit of the good per trading day.

Each trading day on the market consists of three phases, which are organized as follows:

First phase:

At the beginning of a trading you, like all buyers, can make a bid. You can also choose not to make a bid. It is not possible to make more than one bid per trading day. A bid is a price at which you are willing to buy. A bid is binding, that is, it cannot be revoked. The bid has to be in the interval from 1 to 100. Only integers are allowed. When a seller accepts your bid this is the amount you pay for the good.

Together with the price offer you have to indicate the quality you expect to be delivered in case that a seller accepts your bid. It is important that you state your true expectations. Therefore, we ask you to think about it carefully before you make your decision. What the quality could be is described below.

Second phase:

The bids are shown on the computer screens of all buyers and sellers in a descending order. The computer determines the sequence in which sellers can choose from the bids randomly. Each seller can accept at most one bid. A seller can also choose not to accept any bid. The first seller in the sequence can choose from all bids, the second from the remaining bids and so on. This procedure ends if all sellers had the opportunity to choose or if all bids are accepted. Since there are more sellers than buyers, not all sellers will be able to sell a good.

Third phase:

When a seller has accepted a bid he/she has to decide which quality he/she delivers. There are ten different quality levels from which a seller can choose. The lowest quality is $\mathbf{1}$ and the highest quality is 10. Only integer values are allowed. The higher the chosen quality the higher are the costs of the seller and the higher are the earnings of the buyer. On the summary sheet you received from us you find a table. This table shows the costs that come with each quality level. The relation between quality and costs is the same for all sellers and all buyers are informed about this relation too.

Remark: all decisions are anonymous, that means that nobody is informed about the identity of the person that makes a decision. For instance, a buyer is informed whether his or her bid is accepted, but receives no information about who of the sellers has the bid accepted/rejected.

Note: For each good bought buyers have to pay a tax of 20 tokens.

At the end of a trading day the following outcomes are possible:

1. You have not bought a unit of the good. In this case your earnings in this trading day are 0 tokens.

2. You bought a unit. In this case your earnings in this trading day are:

Your earnings from trading (in tokens $)=30+(10 \times$ quality $)-$ price - tax of 20 , or $\mathbf{0}$ tokens if this should be negative. 
The earnings from trading of the seller are:

Earnings from trading of the seller (in tokens) = price - quality costs.

Note: A seller who sells nothing earns 4 tokens.

At the end of a trading day 'your' seller receives information about your 'earnings from trading' and you receive information about the 'earnings from trading' of 'your' seller.

The computer screen you will see shortly consists of 4 parts:

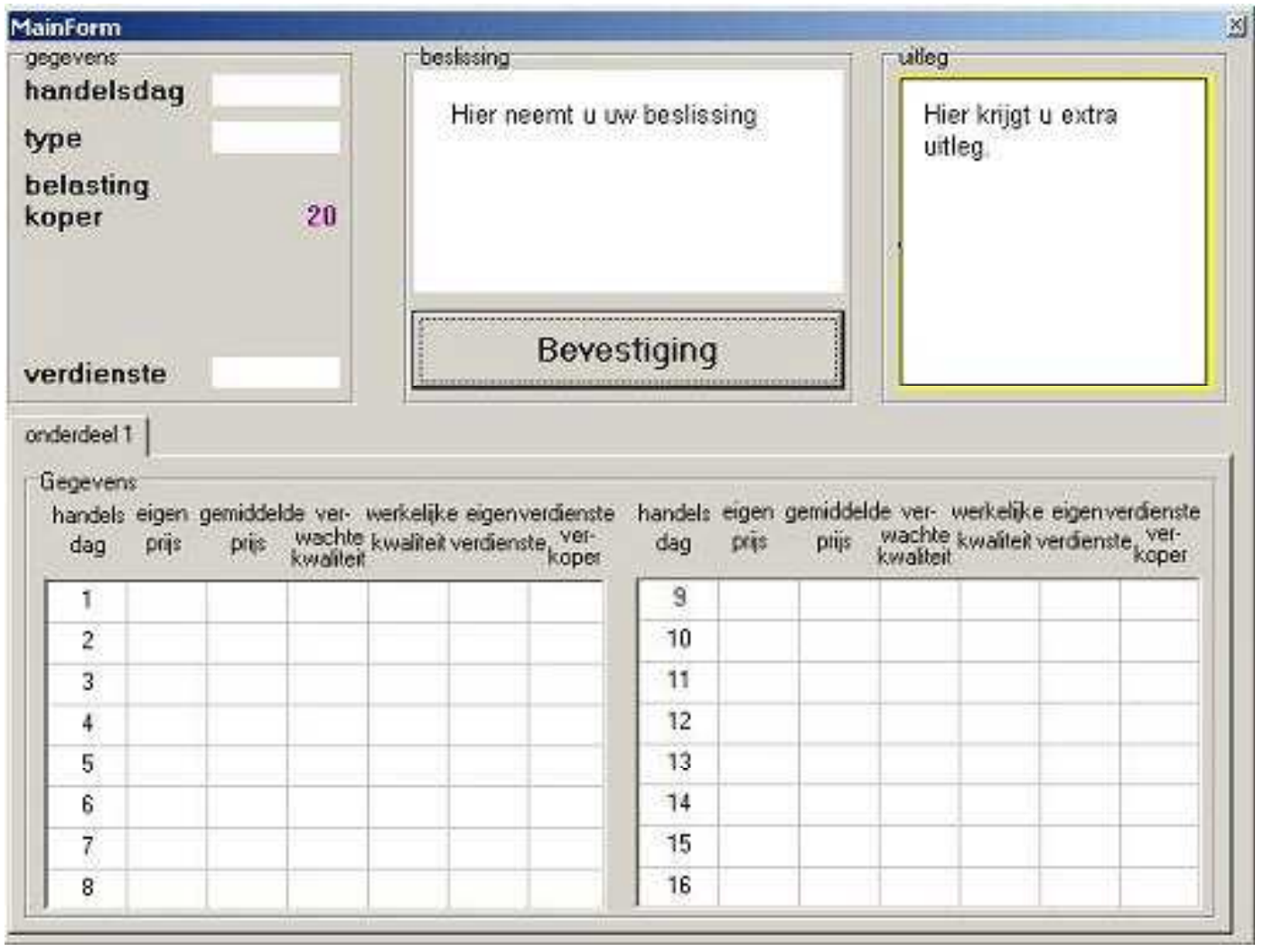

In the upper left part you see your type (in your case 'buyer'), information about the tax, the current trading day and your 'total income' from the previous trading days.

In the upper right part you receive an explanation about the decision you have to make.

In the upper middle part you take your decision. When you have made your decision you have to confirm it by clicking on the button 'Bevestiging' ('confirmation') with the help of the mouse.

In the lower part you receive a summary of the results on each trading day.

If you have a question now, please raise your hand.

If you do not have any questions any more, please click on $\langle\operatorname{KLAAR}\rangle(\langle R E A D Y\rangle)$ and wait for further instructions. 
We ask you to answer a few questions now. These questions serve to test whether you understood the instructions correctly. All questions are based on completely arbitrary examples.

\section{Control question S1}

You have not traded a good on a trading day.

What are your earnings on this trading day?

\section{Control question S2}

You have accepted a 'price bid' of 21 and the 'quality' chosen by you is 8 .

What are your earnings from trading?

What are the earnings from trading of 'your' buyer?

\section{Control question S3}

You have accepted a 'price bid' of 63 and the 'quality' chosen by you is 3 .

What are your earnings from trading?

What are the earnings from trading of 'your' buyer?

\section{Control question S4}

On each trading day you are matched with the same buyer. Right or wrong?

\section{Control questions for buyers (Treatment ToF/ToW)}

We ask you to answer a few questions now. These questions serve to test whether you understood the instructions correctly. All questions are based on completely arbitrary examples.

\section{Control question B1}

You have not traded a good on a trading day.

What are your earnings on this trading day?

\section{Control question B2}

You made a 'price bid' of 21. A seller accepts your bid and chooses a 'quality' of 8 . What are your earnings from trading?

What are the earnings from trading of 'your' seller?

\section{Control question B3}

You made a 'price bid' of 63. A seller accepts your bid and chooses a 'quality' of 3. What are your earnings from trading?

What are the earnings from trading of 'your' seller?

\section{Control question B4}

On each trading day you are matched with the same seller. Right or wrong? 
Instructions part 2 (Treatment ToF/ToW, both types of traders)

This part of the experiment is the same as the first part with one important exception:

Instead of buyers now sellers have to pay a tax of 20 tokens for each unit sold.

The earnings from trading (on a trading day) are now calculated as follows:

Earnings from trading of a buyer (in tokens) $=\mathbf{3 0}+(\mathbf{1 0} \times$ quality $)-$ price, or 0 tokens if this should be negative.

Earnings from trading of a seller (in tokens) = price - quality costs - tax of 20.

A buyer who does not buy earns 0 tokens. A seller who does not sell earns 4 tokens.

Note: This part of the experiment also consists of 16 trading days. There is no practice round. If you have questions please raise your hand. If you do not have any questions any more then please click on $\langle\mathrm{KLAAR}\rangle(\langle R E A D Y\rangle)$ and wait for further instructions.

Summary sheet - seller (Treatment ToF/ToW)

A bid (of a buyer) has to be in the interval from 1 to 100 tokens

Possible quality levels and related costs for a seller (you):

\begin{tabular}{|l|l|l|l|l|l|l|l|l|l|l|}
\hline Quality levels & $\mathbf{1}$ & $\mathbf{2}$ & $\mathbf{3}$ & $\mathbf{4}$ & $\mathbf{5}$ & $\mathbf{6}$ & $\mathbf{7}$ & $\mathbf{8}$ & $\mathbf{9}$ & $\mathbf{1 0}$ \\
\hline Quality costs for a seller & 1 & 2 & 3 & 4 & 5 & 6 & 7 & 8 & 9 & 10 \\
\hline
\end{tabular}

Calculation of earnings (on a trading day):

Your earnings from trading (in tokens) $=$ price - quality costs

If you do not trade a unit of the good you earn 4 tokens.

Earnings from trading of 'your' buyer (in tokens $)=20+(10 \mathrm{x}$ quality $)-$ price - tax of 20 or 0 tokens if this turns out to be negative.

A buyer who does not trade earns 0 tokens. 
Summary sheet - seller (Treatment ToF/ToW) (part 2)

A bid (of a buyer) has to be in the interval from 1 to 100 tokens

Possible quality levels and related costs for a seller (you):

\begin{tabular}{|l|l|l|l|l|l|l|l|l|l|l|}
\hline Quality levels & $\mathbf{1}$ & $\mathbf{2}$ & $\mathbf{3}$ & $\mathbf{4}$ & $\mathbf{5}$ & $\mathbf{6}$ & $\mathbf{7}$ & $\mathbf{8}$ & $\mathbf{9}$ & $\mathbf{1 0}$ \\
\hline Quality costs for a seller & 1 & 2 & 3 & 4 & 5 & 6 & 7 & 8 & 9 & 10 \\
\hline
\end{tabular}

Calculation of earnings (on a trading day):

Your earnings from trading (in tokens) $=$ price - quality costs $-\operatorname{tax}$ of 20

If you do not trade a good you earn 4 tokens.

Earnings from trading of 'your' buyer (in tokens $)=20+(10 \mathrm{x}$ quality $)-$ price or 0 tokens if this turns out to be negative.

Summary sheet - buyer (Treatment ToF/ToW)

A bid (of a buyer) has to be in the interval from 1 to 100 tokens.

Possible quality levels and related costs for a seller:

\begin{tabular}{|l|l|l|l|l|l|l|l|l|l|l|}
\hline Quality levels & $\mathbf{1}$ & $\mathbf{2}$ & $\mathbf{3}$ & $\mathbf{4}$ & $\mathbf{5}$ & $\mathbf{6}$ & $\mathbf{7}$ & $\mathbf{8}$ & $\mathbf{9}$ & $\mathbf{1 0}$ \\
\hline Quality costs for a seller & 1 & 2 & 3 & 4 & 5 & 6 & 7 & 8 & 9 & 10 \\
\hline
\end{tabular}

Calculation of earnings (on a trading day):

Your earnings from trading (in tokens $)=20+(10 \times$ quality $)-$ price - tax of 20 or 0 tokens if this turns out to be negative.

If you do not trade you earn 0 tokens.

Earnings from trading of 'your' seller (in tokens) = price - quality costs

A seller who does not trade earns 4 tokens. 
Summary sheet - buyer (Treatment ToF/ToW) (Part 2)

A bid (of a buyer) has to lie in the interval from 1 to 100 tokens.

Possible quality levels and related costs for a seller:

\begin{tabular}{|l|l|l|l|l|l|l|l|l|l|l|}
\hline Quality levels & $\mathbf{1}$ & $\mathbf{2}$ & $\mathbf{3}$ & $\mathbf{4}$ & $\mathbf{5}$ & $\mathbf{6}$ & $\mathbf{7}$ & $\mathbf{8}$ & $\mathbf{9}$ & $\mathbf{1 0}$ \\
\hline Quality costs for a seller & 1 & 2 & 3 & 4 & 5 & 6 & 7 & 8 & 9 & 10 \\
\hline
\end{tabular}

Calculation of earnings (on a trading day):

Your earnings from trading (in tokens $)=20+(10 \mathrm{x}$ quality $)-$ price or 0 tokens if this turns out to be negative.

If you do not trade you earn 0 tokens.

Earnings from trading of 'your' seller (in tokens) = price - quality costs - tax of 20 A seller who does not trade earns 4 tokens.

The instructions, control questions, and summary sheets for treatment ToF/ToW are identical to those for ToW/ToF except for the parts where the tax is mentioned. There they differ in an obvious way. 


\section{Appendix B1: Average net wages for individual markets}

ToF/ToW

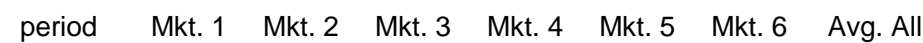

$\begin{array}{llllllll}1 & 43.0 & 42.2 & 43.4 & 50.0 & 37.6 & 31.2 & 41.2\end{array}$

$\begin{array}{llllllll}2 & 43.0 & 39.6 & 43.8 & 46.0 & 47.2 & 20.6 & 40.0\end{array}$

$\begin{array}{llllllll}3 & 55.0 & 35.6 & 51.2 & 50.4 & 53.0 & 37.0 & 47.0\end{array}$

$\begin{array}{llllllll}4 & 61.0 & 41.3 & 57.2 & 50.4 & 52.0 & 46.3 & 51.4\end{array}$

$\begin{array}{llllllll}5 & 59.0 & 41.3 & 61.8 & 46.8 & 58.0 & 65.0 & 55.3\end{array}$

$\begin{array}{llllllll}6 & 54.0 & 50.5 & 59.8 & 45.6 & 59.0 & 49.0 & 53.0\end{array}$

$\begin{array}{llllllll}7 & 58.0 & 44.4 & 60.4 & 48.4 & 44.0 & 31.5 & 47.8\end{array}$

$\begin{array}{llllllll}8 & 48.2 & 43.5 & 58.2 & 57.8 & 41.2 & 34.5 & 47.2\end{array}$

$\begin{array}{llllllll}9 & 52.4 & 47.6 & 61.0 & 46.2 & 43.2 & 32.2 & 47.1\end{array}$

$\begin{array}{llllllll}10 & 64.0 & 48.6 & 51.6 & 57.0 & 50.0 & 52.0 & 53.9\end{array}$

$\begin{array}{llllllll}11 & 61.0 & 46.2 & 58.4 & 47.6 & 46.0 & 39.2 & 49.7\end{array}$

$\begin{array}{llllllll}12 & 62.0 & 51.2 & 57.4 & 50.8 & 39.0 & 28.4 & 48.1\end{array}$

$\begin{array}{llllllll}13 & 58.8 & 62.5 & 56.0 & 47.8 & 43.2 & 39.4 & 51.3\end{array}$

$\begin{array}{llllllll}14 & 59.0 & 60.0 & 56.4 & 51.8 & 38.0 & 28.8 & 49.0\end{array}$

$\begin{array}{llllllll}15 & 60.0 & 65.2 & 65.2 & 46.2 & 44.2 & 28.8 & 51.6\end{array}$

$\begin{array}{llllllll}16 & 58.6 & 65.0 & 62.6 & 45.2 & 32.4 & 21.0 & 47.5\end{array}$

$\begin{array}{llllllll}\text { avg. } 1-16 & 56.1 & 49.0 & 56.5 & 49.2 & 45.5 & 36.6 & 48.8\end{array}$

$\begin{array}{llllllll}17 & 41.0 & 41.0 & 50.4 & 41.4 & 37.0 & 34.0 & 40.8\end{array}$

$\begin{array}{llllllll}18 & 40.0 & 46.4 & 56.2 & 42.2 & 41.2 & 34.0 & 43.3\end{array}$

$\begin{array}{llllllll}19 & 45.0 & 49.6 & 61.0 & 40.2 & 41.4 & 31.0 & 44.7\end{array}$

$\begin{array}{llllllll}20 & 44.0 & 53.4 & 62.4 & 43.2 & 40.6 & 36.2 & 46.6\end{array}$

$\begin{array}{llllllll}21 & 52.0 & 53.4 & 64.8 & 39.2 & 42.0 & 25.8 & 46.2\end{array}$

$\begin{array}{llllllll}22 & 54.0 & 55.6 & 61.4 & 46.5 & 40.6 & 28.3 & 47.7\end{array}$

$\begin{array}{llllllll}23 & 52.4 & 54.8 & 65.0 & 40.0 & 61.5 & 26.6 & 50.1\end{array}$

$\begin{array}{llllllll}24 & 55.8 & 53.4 & 66.4 & 47.8 & 51.8 & 29.3 & 50.7\end{array}$

$\begin{array}{llllllll}25 & 51.0 & 56.4 & 67.0 & 43.2 & 49.2 & 34.6 & 50.2\end{array}$

$\begin{array}{llllllll}26 & 56.0 & 58.4 & 57.2 & 39.4 & 50.2 & 41.8 & 50.5\end{array}$

$\begin{array}{llllllll}27 & 57.0 & 58.8 & 61.0 & 42.8 & 46.4 & 46.5 & 52.1\end{array}$

$\begin{array}{llllllll}28 & 46.0 & 60.2 & 60.8 & 39.4 & 48.4 & 59.0 & 52.3\end{array}$

$\begin{array}{llllllll}29 & 58.0 & 60.8 & 67.8 & 39.4 & 55.5 & 49.2 & 55.1\end{array}$

$\begin{array}{llllllll}30 & 58.0 & 63.8 & 64.2 & 38.8 & 50.6 & 49.4 & 54.1\end{array}$

$\begin{array}{llllllll}31 & 70.0 & 65.0 & 60.6 & 39.6 & 56.8 & 34.3 & 54.4\end{array}$

$\begin{array}{llllllll}32 & 43.2 & 66.6 & 56.0 & 28.4 & 44.2 & 38.6 & 46.2\end{array}$

avg. 17-32 $\begin{array}{lllllll} & 56.5 & 61.4 & 40.7 & 47.3 & 37.4 & 49.1\end{array}$
ToW/ToF

$\begin{array}{lllllll}\text { Mkt. } 1 & \text { Mkt. } 2 & \text { Mkt. } 3 & \text { Mkt. } 4 & \text { Mkt. } 5 & \text { Mkt. } 6 & \text { Avg. All }\end{array}$

$\begin{array}{lllllll}53.0 & 33.3 & 51.3 & 42.5 & 36.0 & 40.0 & 42.7\end{array}$

$\begin{array}{lllllll}60.0 & 17.5 & 55.0 & 50.0 & 39.2 & 39.0 & 43.5\end{array}$

$\begin{array}{lllllll}60.0 & 10.0 & 53.8 & 55.0 & 34.0 & 36.0 & 41.5\end{array}$

$\begin{array}{lllllll}61.3 & 12.5 & 57.5 & 57.3 & 41.4 & 35.0 & 44.2\end{array}$

$\begin{array}{lllllll}63.8 & 16.3 & 57.5 & 57.3 & 32.2 & 19.0 & 41.0\end{array}$

$\begin{array}{lllllll}51.3 & 23.8 & 60.0 & 46.3 & 27.0 & 14.0 & 37.0\end{array}$

$\begin{array}{lllllll}62.5 & 26.8 & 60.0 & 36.3 & 24.8 & 10.0 & 36.7\end{array}$

$\begin{array}{lllllll}63.0 & 25.0 & 60.0 & 48.8 & 31.8 & 13.2 & 40.3\end{array}$

$\begin{array}{lllllll}62.5 & 21.5 & 58.8 & 41.3 & 35.2 & 15.0 & 39.0\end{array}$

$\begin{array}{lllllll}62.5 & 31.8 & 60.0 & 60.7 & 36.4 & 7.8 & 43.2\end{array}$

$\begin{array}{lllllll}62.5 & 46.0 & 60.0 & 45.0 & 26.2 & 9.5 & 41.5\end{array}$

$\begin{array}{lllllll}62.5 & 61.3 & 60.0 & 47.5 & 27.2 & 8.6 & 44.5\end{array}$

$\begin{array}{lllllll}62.5 & 58.8 & 60.0 & 43.8 & 26.2 & 9.2 & 43.4\end{array}$

$\begin{array}{lllllll}62.5 & 63.8 & 60.0 & 47.5 & 32.8 & 10.0 & 46.1\end{array}$

$\begin{array}{lllllll}61.3 & 73.3 & 60.0 & 33.3 & 34.2 & 13.3 & 45.9\end{array}$

$\begin{array}{lllllll}52.5 & 75.0 & 60.0 & 47.5 & 38.2 & 6.8 & 46.7\end{array}$

$\begin{array}{lllllll}60.2 & 37.3 & 58.4 & 47.5 & 32.7 & 17.9 & 42.3\end{array}$

$\begin{array}{lllllll}62.5 & 53.5 & 55.0 & 50.0 & 37.4 & 36.8 & 49.2\end{array}$

$\begin{array}{lllllll}57.5 & 48.8 & 57.5 & 47.5 & 38.8 & 13.4 & 43.9\end{array}$

$\begin{array}{lllllll}61.3 & 51.3 & 60.0 & 60.0 & 39.2 & 9.2 & 46.8\end{array}$

$\begin{array}{lllllll}61.3 & 46.3 & 60.0 & 60.0 & 27.4 & 11.0 & 44.3\end{array}$

$\begin{array}{lllllll}60.0 & 65.0 & 60.0 & 60.0 & 22.2 & 10.8 & 46.3\end{array}$

$\begin{array}{lllllll}60.0 & 66.3 & 60.0 & 52.5 & 30.0 & 16.4 & 47.5\end{array}$

$\begin{array}{lllllll}60.0 & 70.0 & 60.0 & 57.5 & 24.6 & 17.0 & 48.2\end{array}$

$\begin{array}{lllllll}62.5 & 71.3 & 60.0 & 60.0 & 16.2 & 26.8 & 49.5\end{array}$

$\begin{array}{lllllll}61.3 & 75.0 & 60.0 & 60.0 & 22.2 & 25.2 & 50.6\end{array}$

$\begin{array}{lllllll}60.0 & 53.3 & 60.0 & 56.3 & 23.8 & 26.2 & 46.6\end{array}$

$\begin{array}{lllllll}61.3 & 73.3 & 51.3 & 60.0 & 18.8 & 21.8 & 47.7\end{array}$

$\begin{array}{lllllll}62.5 & 57.5 & 60.0 & 52.5 & 16.2 & 20.6 & 44.9\end{array}$

$\begin{array}{lllllll}61.3 & 77.5 & 60.0 & 60.0 & 17.4 & 19.6 & 49.3\end{array}$

$\begin{array}{lllllll}61.3 & 73.8 & 60.0 & 62.3 & 16.2 & 29.4 & 50.5\end{array}$

$\begin{array}{lllllll}61.3 & 74.8 & 60.0 & 50.3 & 21.8 & 34.2 & 50.4\end{array}$

$\begin{array}{lllllll}60.0 & 61.5 & 60.0 & 60.5 & 14.6 & 11.2 & 44.6\end{array}$

$\begin{array}{lllllll}60.9 & 63.7 & 59.0 & 56.8 & 24.2 & 20.6 & 47.5\end{array}$ 


\section{Appendix B2: Average efforts for individual markets}

ToF/ToW

$\begin{array}{lllllll}\text { period Mkt. } 1 & \text { Mkt. } 2 & \text { Mkt. } 3 & \text { Mkt. } 4 & \text { Mkt. } 5 & \text { Mkt. } 6 & \begin{array}{c}\text { Avg. All } \\ \text { Mkts }\end{array}\end{array}$

\begin{tabular}{|c|c|c|c|c|c|c|c|c|c|c|c|c|c|c|}
\hline 1 & 4.0 & 4.2 & 5.4 & 8.0 & 4.0 & 3.6 & 4.9 & 5.5 & 2.0 & 5.3 & 3.3 & 3.8 & 2.0 & 3.6 \\
\hline 2 & 4.2 & 4.0 & 6.6 & 4.2 & 3.6 & 2.0 & 4.1 & 9.0 & 1.3 & 7.3 & 5.3 & 5.4 & 1.2 & 4.9 \\
\hline 3 & 6.2 & 4.2 & 7.0 & 7.2 & 3.2 & 4.2 & 5.3 & 6.0 & 1.3 & 6.5 & 6.8 & 1.0 & 3.4 & 4.2 \\
\hline 4 & 6.0 & 6.3 & 7.4 & 6.2 & 6.4 & 3.8 & 6.0 & 6.5 & 1.5 & 6.0 & 6.3 & 2.6 & 1.5 & 4.1 \\
\hline 5 & 6.6 & 3.0 & 8.0 & 6.6 & 6.6 & 6.5 & 6.2 & 7.8 & 2.5 & 8.8 & 5.5 & 4.0 & 2.6 & 5.2 \\
\hline 6 & 4.4 & 4.3 & 8.6 & 7.4 & 5.6 & 3.4 & 5.6 & 5.5 & 3.3 & 7.8 & 4.5 & 3.8 & 2.0 & 4.5 \\
\hline 7 & 5.6 & 5.4 & 8.0 & 8.0 & 5.6 & 2.0 & 5.8 & 7.5 & 3.0 & 10.0 & 6.5 & 1.8 & 1.3 & 5.0 \\
\hline 8 & 4.8 & 7.0 & 7.2 & 7.3 & 4.4 & 4.5 & 5.9 & 9.5 & 3.0 & 9.8 & 3.8 & 3.2 & 1.8 & 5.2 \\
\hline 9 & 5.8 & 5.6 & 8.0 & 6.2 & 3.4 & 3.0 & 5.3 & 10.0 & 1.5 & 9.3 & 5.3 & 4.4 & 1.2 & 5.3 \\
\hline 10 & 8.0 & 5.8 & 6.8 & 8.0 & 3.8 & 6.8 & 6.5 & 7.8 & 3.3 & 8.5 & 7.7 & 1.8 & 1.0 & 5.0 \\
\hline 11 & 6.2 & 5.8 & 7.8 & 6.0 & 5.0 & 3.8 & 5.8 & 7.8 & 3.8 & 9.0 & 2.7 & 2.8 & 1.0 & 4.5 \\
\hline 12 & 5.2 & 5.8 & 7.0 & 7.8 & 5.0 & 4.6 & 5.9 & 7.8 & 5.5 & 9.8 & 6.0 & 3.6 & 1.0 & 5.6 \\
\hline 13 & 3.3 & 5.3 & 7.4 & 6.8 & 4.6 & 3.2 & 5.1 & 5.5 & 7.5 & 9.5 & 5.0 & 3.0 & 1.2 & 5.3 \\
\hline 14 & 5.2 & 7.5 & 7.2 & 7.6 & 3.3 & 2.2 & 5.5 & 3.3 & 4.0 & 9.5 & 3.5 & 3.6 & 1.4 & 4.2 \\
\hline 15 & 7.0 & 7.6 & 8.8 & 7.2 & 5.8 & 3.8 & 6.7 & 4.5 & 6.7 & 10.0 & 5.3 & 3.8 & 1.0 & 5.2 \\
\hline 16 & 6.0 & 6.4 & 7.2 & 4.4 & 3.0 & 1.0 & 4.7 & 3.3 & 7.5 & 7.8 & 7.5 & 2.8 & 1.2 & 5.0 \\
\hline avg. 1-16 & 5.5 & 5.5 & 7.4 & 6.8 & 4.6 & 3.6 & 5.6 & 6.7 & 3.6 & 8.4 & 5.3 & 3.2 & 1.5 & 4.8 \\
\hline 17 & 3.8 & 5.8 & 7.6 & 6.2 & 4.0 & 4.6 & 5.3 & 5.5 & 4.5 & 5.0 & 5.5 & 3.6 & 1.0 & 4.2 \\
\hline 18 & 4.0 & 5.2 & 8.6 & 6.2 & 3.0 & 5.3 & 5.4 & 8.0 & 3.3 & 7.8 & 5.8 & 5.0 & 1.2 & 5.2 \\
\hline 19 & 6.0 & 5.4 & 9.2 & 6.4 & 3.8 & 2.8 & 5.6 & 7.8 & 5.0 & 8.5 & 8.3 & 1.6 & 1.4 & 5.4 \\
\hline 20 & 6.0 & 7.0 & 8.8 & 5.6 & 5.8 & 2.8 & 6.0 & 5.5 & 6.5 & 5.5 & 6.8 & 2.4 & 1.0 & 4.6 \\
\hline 21 & 7.6 & 5.4 & 9.0 & 5.2 & 5.4 & 1.6 & 5.7 & 5.5 & 7.3 & 7.8 & 5.7 & 3.0 & 1.6 & 5.1 \\
\hline 22 & 6.0 & 5.6 & 8.0 & 7.3 & 4.6 & 2.0 & 5.6 & 5.5 & 6.8 & 6.8 & 6.3 & 3.0 & 1.8 & 5.0 \\
\hline 23 & 7.4 & 7.0 & 9.0 & 6.2 & 7.3 & 2.0 & 6.5 & 6.5 & 6.3 & 4.8 & 8.8 & 3.0 & 2.0 & 5.2 \\
\hline 24 & 6.4 & 8.2 & 8.8 & 4.5 & 7.2 & 4.3 & 6.6 & 10.0 & 5.3 & 8.8 & 6.8 & 1.4 & 3.0 & 5.9 \\
\hline 25 & 6.0 & 6.6 & 8.8 & 5.4 & 3.8 & 3.6 & 5.7 & 7.8 & 6.0 & 8.8 & 4.5 & 3.2 & 2.4 & 5.4 \\
\hline 26 & 7.8 & 7.4 & 8.2 & 5.2 & 2.2 & 4.0 & 5.8 & 7.8 & 3.8 & 8.3 & 6.5 & 1.4 & 2.6 & 5.0 \\
\hline 27 & 7.4 & 7.0 & 8.0 & 5.6 & 6.6 & 5.0 & 6.6 & 7.8 & 6.3 & 7.3 & 5.5 & 2.0 & 1.8 & 5.1 \\
\hline 28 & 5.2 & 6.6 & 7.0 & 6.0 & 5.4 & 7.6 & 6.3 & 7.8 & 5.5 & 9.5 & 5.5 & 1.6 & 1.6 & 5.2 \\
\hline 29 & 6.6 & 5.4 & 8.6 & 5.2 & 6.8 & 4.4 & 6.2 & 5.5 & 8.0 & 9.8 & 6.8 & 1.4 & 3.0 & 5.7 \\
\hline 30 & 6.8 & 5.8 & 7.2 & 5.0 & 4.6 & 2.4 & 5.3 & 7.8 & 6.0 & 7.5 & 7.0 & 1.2 & 2.6 & 5.3 \\
\hline 31 & 6.3 & 7.4 & 8.0 & 4.6 & 2.2 & 3.3 & 5.3 & 5.5 & 5.8 & 9.0 & 5.5 & 3.0 & 1.6 & 5.1 \\
\hline 32 & 2.8 & 4.6 & 4.6 & 1.2 & 2.4 & 1.0 & 2.8 & 3.3 & 4.3 & 7.8 & 7.8 & 1.0 & 2.0 & 4.3 \\
\hline avg. 17-32 & 6.0 & 6.3 & 8.1 & 5.4 & 4.7 & 3.5 & 5.7 & 6.7 & 5.6 & 7.7 & 6.4 & 2.4 & 1.9 & 5.1 \\
\hline
\end{tabular}

ToW/ToF

$\begin{array}{lllllll}\text { Mkt. } 1 & \text { Mkt. } 2 & \text { Mkt. } 3 & \text { Mkt. } 4 & \text { Mkt. } 5 & \text { Mkt. } 6 & \text { Avg. All }\end{array}$ Mkts

1

2

3$$
6
$$

.2$$
5.4
$$$$
.6
$$$$
5.1
$$$$
5.9
$$$$
5.4
$$$$
5
$$$$
1
$$ 